\title{
Accumulation and cellular toxicity of aluminum in seedling of Pinus massoniana
}

\author{
Huanhuan Zhang ${ }^{1}$, Ze Jiang ${ }^{1}$, Rong Qin ${ }^{1,2}$, Huaning Zhang ${ }^{1}$, Jinhua Zou', Wusheng Jiang ${ }^{1}$ and Donghua Liu*
}

\begin{abstract}
Background: Masson pine (Pinus massoniana) is one of the most important timber species with adaptable, fast growing, versatile advantages in southern China. Despite considerable research efforts, the cellular and molecular mechanisms of A1 toxicity and resistance in P. massoniana are still poorly understood. The effects of Al on uptake and translocation of $\mathrm{Al}$ and other minerals, cell division and nucleolus in $P$. massoniana were investigated.

Results: The results indicated that Al accumulated mainly in the roots, and small amounts were transported to aboveground organs. In the presence of $\mathrm{Al}$, the contents of $\mathrm{Mg}$ and Fe in stems increased and decreased in roots. Accumulation of $\mathrm{Mn}$ in the organs was inhibited significantly. Evidence from cellular experiments showed that Al had an inhibitory effect on the root growth at all concentrations $\left(10^{-5}-10^{-2} \mathrm{M}\right)$ used. Chromosome fragments, chromosome bridges, C-mitosis and chromosome stickiness were induced during mitosis in the root tip cells. Al induced the formation of abnormal microtubule (MT) arrays, consisting of discontinuous wavy MTs or short MT fragments at the cell periphery. MT organization and function of the mitotic spindle and phragmoplast were severely disturbed. The nucleolus did not disaggregate normally and still remained its characteristic structure during metaphase. Nucleolar particles containing argyrophilic proteins were accumulated and leached out from the nucleus to the cytoplasm. Evidence confirmed that these proteins contained nucleophosmin (B23), nucleolin (C23) and fibrillarin. Western immunoblot analysis revealed that the contents of three nucleolar proteins increased significantly.

Conclusion: Based on the information provided in this article, it is concluded that root tips of plants are the most sensitive organ to environmental stresses and the accumulation of Al ions primarily is in roots of P. massoniana, and small amounts of Al are transported to aboveground. Root apical meristems play a key role in the immediate reaction to stress factors by activating signal cascades to the other plant organs. Al induces a series of the cellular toxic changes concerning with cell division and nucleolus. The data presented above can be also used as valuable and early markers in cellular changes induced by metals for the evaluation of metal contamination.
\end{abstract}

Keywords: Pinus massoniana, Aluminum (Al), Cell division, Microtubules, Nucleolar organizing region, Nucleolar proteins

\section{Background}

Aluminium (Al) ranks third in abundance among the Earth's crust elements, after oxygen and silicon, and is the most abundant metallic element [1,2]. Al is a ubiquitous element without a known, specific and biological function in plant metabolism [3]. However, the metal is considered to be a major growth-limiting factor particularly in acid soils $(\mathrm{pH}<5.0)$, which are estimated to be approximately $30-40 \%$ of arable lands in the world [4]. Once the $\mathrm{pH}$ decreases below 5.0, $\mathrm{Al}$ is solubilized into a phytotoxic

\footnotetext{
* Correspondence: donghua@mail.zlnet.com.cn

${ }^{1}$ Tianjin Key Laboratory of Animal and Plant Resistance, College of Life

Sciences, Tianjin Normal University, Tianjin 300387, PR China

Full list of author information is available at the end of the article
}

form, mainly as $\mathrm{Al}^{3+}$ from nonphytotoxic silicate or oxide forms which restricts plant growth [5].

It is well known that $\mathrm{Al}$, for most crops, is a serious constraint, although some crops (e.g., pineapple and tea) are considered to be tolerant to high levels of exchangeable Al. Species and genotypes within species greatly differ in their tolerance to $\mathrm{Al}$ [2]. Investigations on the toxicity and resistance mechanisms have often been performed taking physiological and genetic basis of resistance into consideration [6,7]. Some investigations indicate that $\mathrm{Al}$ uptake is limited mainly to the root system, where it accumulates predominantly in the epidermis and the outer cortex $[8,9]$. And the others demonstrate that some plant species, such as some species native to the region of 
central Brazil, can accumulate considerable amounts of $\mathrm{Al}$ in their shoots $[9,10]$. Due to its importance in limiting agricultural and forest productivity, there have been numerous studies that describe the toxic effects of $\mathrm{Al}$ on plant root growth and physiology [11,12]. Probing root meristem as a plant bioassay system for $\mathrm{Al}$ toxicity testing has been suggested since many plants are known to be injured by $\mathrm{Al}$ under natural and experimental exposure conditions. It has been well known that $\mathrm{Al}$ toxicity is performed primarily by inhibition of root growth [13], and the root meristem is one of the most sensitive sites to $\mathrm{Al}$ toxicity [14].

Masson pine (Pinus massoniana) is one of the most important timber species with adaptable, fast growing, versatile advantages in southern China [15]. P. massoniana occupies a very important position in China's forestry development and forest resources cultivation, and has expanded rapidly to reach an estimated area of 5.7 million hectares [16]. It was reported that due to heavy chemical fertilization the soil $\mathrm{pH}$ in the major Chinese crop-production areas declined significantly from the 1980s to the 2000s [17]. Al toxicity due to soil acidification has become the main reason for the decline of the forest [18]. Despite considerable research efforts, the cellular and molecular mechanisms of A1 toxicity and resistance in P. massoniana are still poorly understood.

The effect of $\mathrm{Al}$ on uptake and translocation of $\mathrm{Al}$ and other minerals ( $\mathrm{Fe}, \mathrm{Mn}$ and $\mathrm{Mg}$ ), cell division and nucleolus in $P$. massoniana were carried out in order to understanding the mechanisms of $\mathrm{Al}$-induced toxicity.

\section{Results}

\section{Al accumulation and its effect on other minerals} Al accumulation

$\mathrm{Al}$ uptake and accumulation in roots, leaves and shoots of $P$. massoniana varied depending on $\mathrm{Al}$ concentration. The Al contents increased significantly $(p<0.05)$ with increasing $\mathrm{Al}$ concentration in the nutrient solutions (Table 1). The accumulation of Al primarily was in roots, and small amounts of $\mathrm{Al}$ were transported to stems and leaves. Levels of $\mathrm{Al}$ in $P$. massoniana treated with $10^{-5} \mathrm{M}$

Table 1 Al content in different organs of Pinus massoniana L. exposed to different concentrations after $\mathbf{4 0} \mathrm{d}$ treatment

\begin{tabular}{llll}
\hline $\begin{array}{l}\text { Treatment } \\
(\mathbf{A l}, \mathbf{M})\end{array}$ & \multicolumn{3}{l}{ Organs $(\boldsymbol{\mu g} / \mathbf{g ~ D W} \pm \mathbf{S E})$} \\
\cline { 2 - 4 } & Roots & Leaves & Stems \\
\hline Control & $23.02 \pm 0.22 \mathrm{e}$ & $18.33 \pm .021 \mathrm{e}$ & $9.38 \pm 0.26 \mathrm{~d}$ \\
$10^{-5}$ & $373.75 \pm 4.82 \mathrm{~d}$ & $87.83 \pm 9.99 \mathrm{~d}$ & $24.25 \pm 1.84 \mathrm{~d}$ \\
$10^{-4}$ & $3384.66 \pm 19.82 \mathrm{C}$ & $171.25 \pm 10.85 \mathrm{C}$ & $120.55 \pm 1.58 \mathrm{c}$ \\
$10^{-3}$ & $10024.62 \pm 83.66 \mathrm{~b}$ & $278.47 \pm 1.91 \mathrm{~b}$ & $226.56 \pm 3.34 \mathrm{~b}$ \\
$10^{-2}$ & $14712.89 \pm 36.94 \mathrm{a}$ & $1383.98 \pm 4.41 \mathrm{a}$ & $3340.84 \pm 12.07 \mathrm{a}$
\end{tabular}

Values followed by different letters are significantly different $(P<0.05)$. Vertical bars denote $\mathrm{SE}(\mathrm{n}=3)$. to $10^{-3} \mathrm{M} \mathrm{Al}$ were in the order: roots $>$ leaves $>$ stems, while contents in the treatment group exposed to $10^{-2} \mathrm{M}$ $\mathrm{Al}$ were in the order as follows: roots > stems > leaves. The over ground parts (stems and leaves)/roots ratios at $10^{-4} \mathrm{M}$ and $10^{-3} \mathrm{M} \mathrm{Al}$ after $40 \mathrm{~d}$ of $\mathrm{Al}$ treatment were $8.6 \%$ and $5 \%$, respectively. However, the ratios at $10^{-5} \mathrm{M}$ and $10^{-2} \mathrm{M} \mathrm{Al}$ were higher: they were $30 \%$ and $32.1 \%$, respectively.

\section{Effects of $\mathrm{Al}$ on levels of $\mathrm{Mg}, \mathrm{Fe}$ and $\mathrm{Mn}$}

$P$. massoniana seedlings exposed to Al solution substantially affected the uptake and distribution of $\mathrm{Mg}$, Fe and $\mathrm{Mn}$ in plants. The results indicated that the contents of $\mathrm{Mg}$ and Fe increased in stems of P. massoniana seedlings and decreased in roots with increasing Al. While the contents of $\mathrm{Fe}$ in the roots and the leaves decreased. Besides, uptake and accumulation of $\mathrm{Mn}$ in the organs were inhibited significantly $(P<0.05)$ under $\mathrm{Al}$ stress (Table 2).

\section{Effects of Al on cell division and nucleoli Effects of Al on root growth}

The effects of $\mathrm{Al}$ on the root growth of P. massonian varied with the different concentrations of aluminum chloride solutions used (Figures 1 and 2). Al had an inhibitory effect on the root growth at all concentrations $\left(10^{-5}-10^{-2} \mathrm{M}\right)$ used during the entire treatment $(72 \mathrm{~h})$. At $10^{-3}-10^{-2} \mathrm{M} \mathrm{Al}$, the root length was strongly inhibited after $24 \mathrm{~h}$ of treatment.

\section{Effects of Al on chromosome morphology}

The standard types of aberrant chromosomes (modified Allium test introduced by Fiskesjö [19]), were observed in the root tip cells of $P$. massoniana after treatment with $\mathrm{Al}$. The toxic effects of $\mathrm{Al}$ on chromosome behavior in root tips of $P$. massoniana varied with the different $\mathrm{Al}$ concentrations and the treatment time (Figure 3). Several types of chromosomal aberrations were observed when compared with control. At low concentration $\left(10^{-5} \mathrm{M} \mathrm{Al}\right)$, $\mathrm{C}$-mitosis induced by $\mathrm{Al}$ in the present investigation is major type of chromomsomal aberrations and the highly condensed chromosomes were scattered randomly in root tip cells (Figure 3A). Chromosome fragments in some root tip cells were also observed at $10^{-5} \mathrm{M} \mathrm{Al}$ (Figure 3B). Anaphase bridges involving one or more chromosomes (Figure 3C-D) were found after the treatment with $10^{-4} \mathrm{M}$ Al. Chromosome stickiness consisted of anaphase sticky bridges $\left(10^{-3} \mathrm{M} \mathrm{Al}\right)$ (Figure $\left.3 \mathrm{E}\right)$ and metaphase sticky chromosomes $\left(10^{-2} \mathrm{M} \mathrm{Al}\right)$ (Figure $3 \mathrm{~F}$ ), which is major type of chromosomal aberrations at high concentration of Al. This type of toxic effect is most likely irreversible, which probably led to cell death. 
Table 2 Effects of $\mathrm{Al}$ on accumulation of $\mathrm{Mg}$, Fe and $\mathrm{Mn}$ in roots, stems and leaves of Pinus massoniana

\begin{tabular}{|c|c|c|c|c|}
\hline \multirow{2}{*}{ Element } & \multirow{2}{*}{ Treatment (AI, M) } & \multicolumn{3}{|c|}{ Organs $(\mu \mathrm{g} / \mathrm{g} D W \pm S E)$} \\
\hline & & Roots & Roots & Roots \\
\hline \multirow[t]{5}{*}{$\mathrm{Mg}$} & Control & $1550.67 \pm 11.07 a$ & $1169.62 \pm 3.15 \mathrm{e}$ & $2777.18 \pm 4.15 a$ \\
\hline & $10^{-5}$ & $1533.11 \pm 5.06 a$ & $1331.27 \pm 0.55 d$ & $2734.00 \pm 14.40 \mathrm{ab}$ \\
\hline & $10^{-4}$ & $1378.91 \pm 11.64 b$ & $1421.89 \pm 3.54 c$ & $2661.81 \pm 20.09 c$ \\
\hline & $10^{-3}$ & $1196.43 \pm 9.65 c$ & $2088.24 \pm 4.17 b$ & $2719.36 \pm 9.03 b$ \\
\hline & $10^{-2}$ & $1158.62 \pm 8.18 \mathrm{~d}$ & $2710.64 \pm 16.92 a$ & $2716.34 \pm 27.94 b$ \\
\hline \multirow[t]{5}{*}{$\mathrm{Fe}$} & Control & $990.08 \pm 9.42 \mathrm{a}$ & $49.59 \pm 7.39 c$ & $207.84 \pm 6.50 a$ \\
\hline & $10^{-5}$ & $895.83 \pm 2.94 b$ & $53.58 \pm 0.55 c$ & $194.45 \pm 0.83 b$ \\
\hline & $10^{-4}$ & $725.19 \pm 3.11 c$ & $87.92 \pm 2.39 b$ & $178.04 \pm 0.63 c$ \\
\hline & $10^{-3}$ & $519.29 \pm 5.25 d$ & $92.22 \pm 2.30 b$ & $116.23 \pm 0.93 e$ \\
\hline & $10^{-2}$ & $302.56 \pm 2.79 e$ & $138.34 \pm 1.30 \mathrm{a}$ & $141.58 \pm .69 d$ \\
\hline \multirow[t]{5}{*}{$\mathrm{Mn}$} & Control & $302.00 \pm 2.14 a$ & $10.05 \pm 0.12 a$ & $125.07 \pm 0.08 a$ \\
\hline & $10^{-5}$ & $165.67 \pm 0.64 b$ & $9.24 \pm 0.21 b$ & $59.53 \pm 0.41 c$ \\
\hline & $10^{-4}$ & $151.99 \pm 0.55 c$ & $8.28 \pm 0.24 c$ & $61.56 \pm 0.14 b$ \\
\hline & $10^{-3}$ & $12.81 \pm 0.29 d$ & $6.75 \pm 0.10 d$ & $20.56 \pm 0.15 d$ \\
\hline & $10^{-2}$ & $9.13 \pm 0.08 \mathrm{e}$ & $5.18 \pm 0.19 \mathrm{e}$ & $11.81 \pm 0.14 \mathrm{e}$ \\
\hline
\end{tabular}

Values followed by different letters are significantly different $(P<0.05)$. Vertical bars denote SE $(n=3)$.

\section{Effects of Al on the organization of MT cytoskeleton}

In controls, cortical microtubules (MTs) of meristematic cells were very abundant during interphase. They were found roughly parallel to each other and were oriented perpendicular to the primary axis of cell expansion (Figure 4A). Al caused the changes in the organization of microtubular cytoskeleton in $P$. massoniana cells. Some cells displaying aberrant cortical MTs were found after $24 \mathrm{~h}$ treatment with
$10^{-5} \mathrm{M}$ Al. In these cells MT organization was traversed by slightly skewed wavy (Figure 4B). When cells exposed to $10^{-4} \mathrm{M} \mathrm{Al}$ for $48 \mathrm{~h}$, the cortical MTs of some cells lost their transverse organization. Instead, they were randomly oriented, often discontinuous and form numerous short MT fragments of different size at the cell periphery (Figure 4C-D). MT stickiness was observed in some cells treated with $10^{-3} \mathrm{M} \mathrm{Al}$ for $48 \mathrm{~h}$. The proportion of

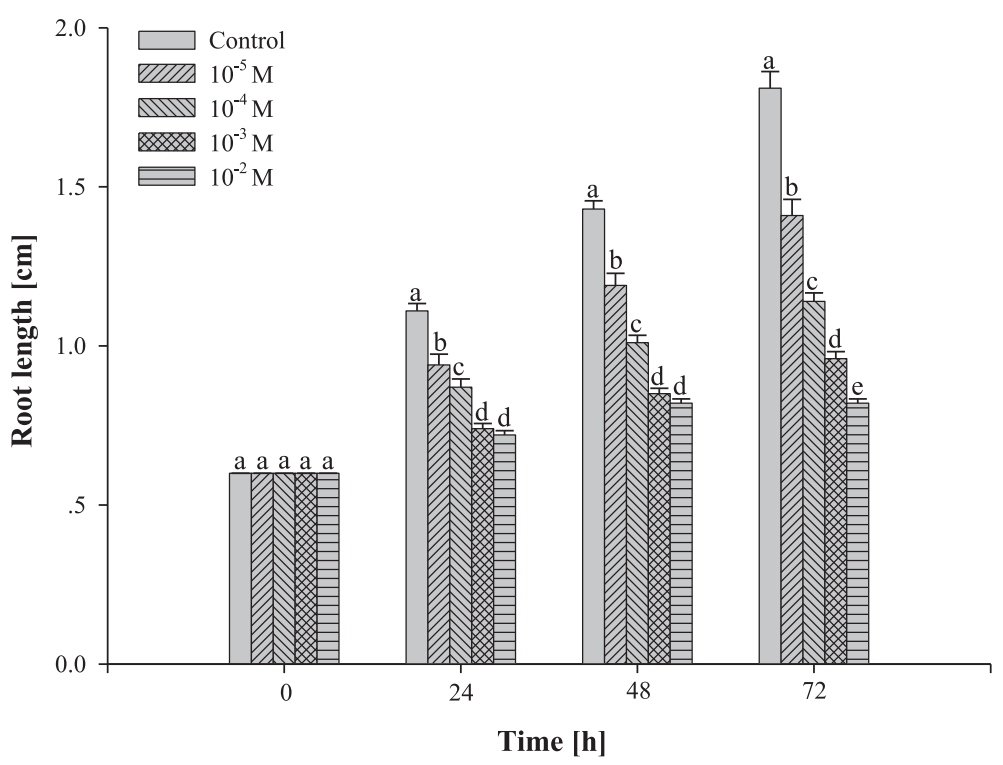

Figure 1 Effects of different concentrations of Al on root length of $P$. massoniana stressed for 24,48 and 72 h. Values with different letters differ significantly from each other $(n=10, P<0.05)$. 


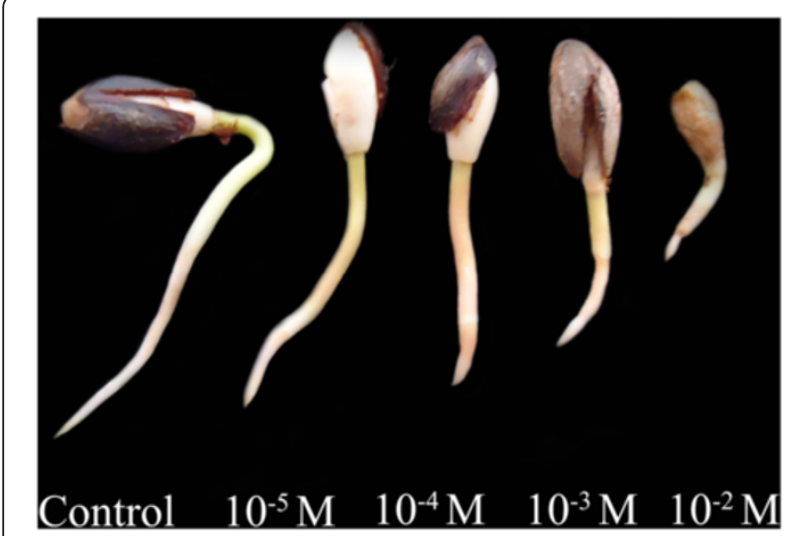

Figure 2 Effects of different concentrations of $\mathrm{Al}$ on seedling growth of $P$. massoniana during the whole treatment $(72 \mathrm{~h})$.

abnormal MTs increased depending on $\mathrm{Al}$ concentrations and duration of treatment. Evidences above suggested that Al damaged structure of cortical MTs.

In metaphase and anaphase cells of control, the typical mitotic spindles is that spindle MTs become oriented into a bipolar array whose dyad axis divided the structure into two half spindles, and sister chromatids were segregated by moving them to opposite poles (Figure 5A). The changes of MT cytoskeleton induced by $\mathrm{Al}$ were closely related to chromosome aberrations (anaphase bridges, $\mathrm{C}$-mitosis and chromosome stickiness) during mitosis. The significant changes in MT cytoskeleton were noted in the cells exposed to $10^{-4} \mathrm{M} \mathrm{Al}$ after $24 \mathrm{~h}$, revealing some sticky spindle MTs split into discontinuous MT fragments in the procession of moving sister chromatids to opposite poles (Figure 5B). With increasing $\mathrm{Al}$ concentration and duration of treatment, spindle MT arrays were mostly depolymerized in some cells, resulting in the formation of chromosome stickiness (Figure 5C). In control cells, phragmoplast expanded centrifugally until it contacted the parent cell walls and daughter chromosomes were reorganized into new nuclei (Figure 5D). Phragmoplast could not be formed due to damage of MTs of the mitotic spindle in anaphase cells treated with $10^{-3} \mathrm{M} \mathrm{Al}$ after $48 \mathrm{~h}$ (Figure 5E).

\section{Effects of Al on nucleolar cycle during mitosis}

The nucleolar cycle of silver-impregnated $P$. massoniana cells was examined by means of light microscopy. Normally, the nucleoli in interphase nuclei impregnated with silver showed strong staining (Figure 6A). Then the prophase decondensed chromatin fibers appeared gradually and were around the nucleoli (Figure 6B-C). During prometaphase-metaphase, the nucleoli became small in size (Figure 6D). The nucleoli disappeared completely in their characteristic structures and nucleolar organizing regions (NORs) were localized on metaphase chromosomes (Figure 6E). NORs were migrated with the chromosomes to the poles at anaphase (Figure 6F). The newly forming nucleoli around the NORs were rebuilt at telophase (Figure 6G). Mitosis was completed. After the treatment with $\mathrm{Al}$, the abnormal phenomena of the nucleolar cycle during mitosis were examined in
A
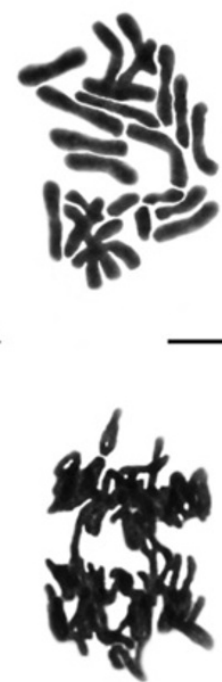

B
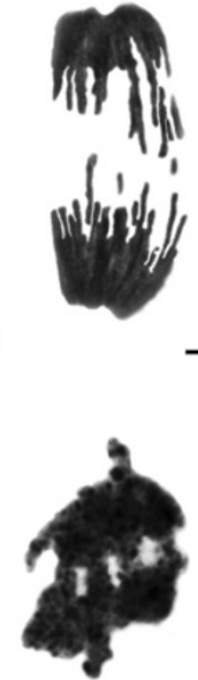

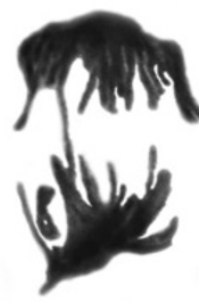

$\mathrm{C}$

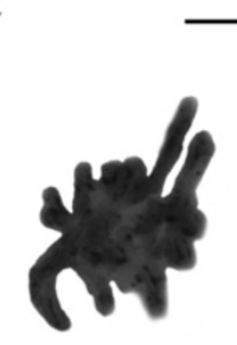

D

E

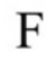

Figure 3 Effects of $\mathbf{A l}$ on root tip cells division of P. Massoniana. A. C-mitosis (10 $\left.0^{-5} \mathrm{M} \mathrm{Al}, 24 \mathrm{~h}\right)$. B. Chromosome fragments $\left(10^{-5} \mathrm{M} \mathrm{Al}, 24 \mathrm{~h}\right)$ C-D. Chromosome bridges (C-D. $10^{-4} \mathrm{M} \mathrm{Al}, 72 \mathrm{~h}$ ). E. Sticky chromosome bridges (E. $10^{-3} \mathrm{M} \mathrm{Al}, 72 \mathrm{~h}$ ). F. Chromosome stickiness (10 $0^{-2} \mathrm{M} \mathrm{Al}, 48$ h). Scale bar $=10 \mu \mathrm{m}$. 


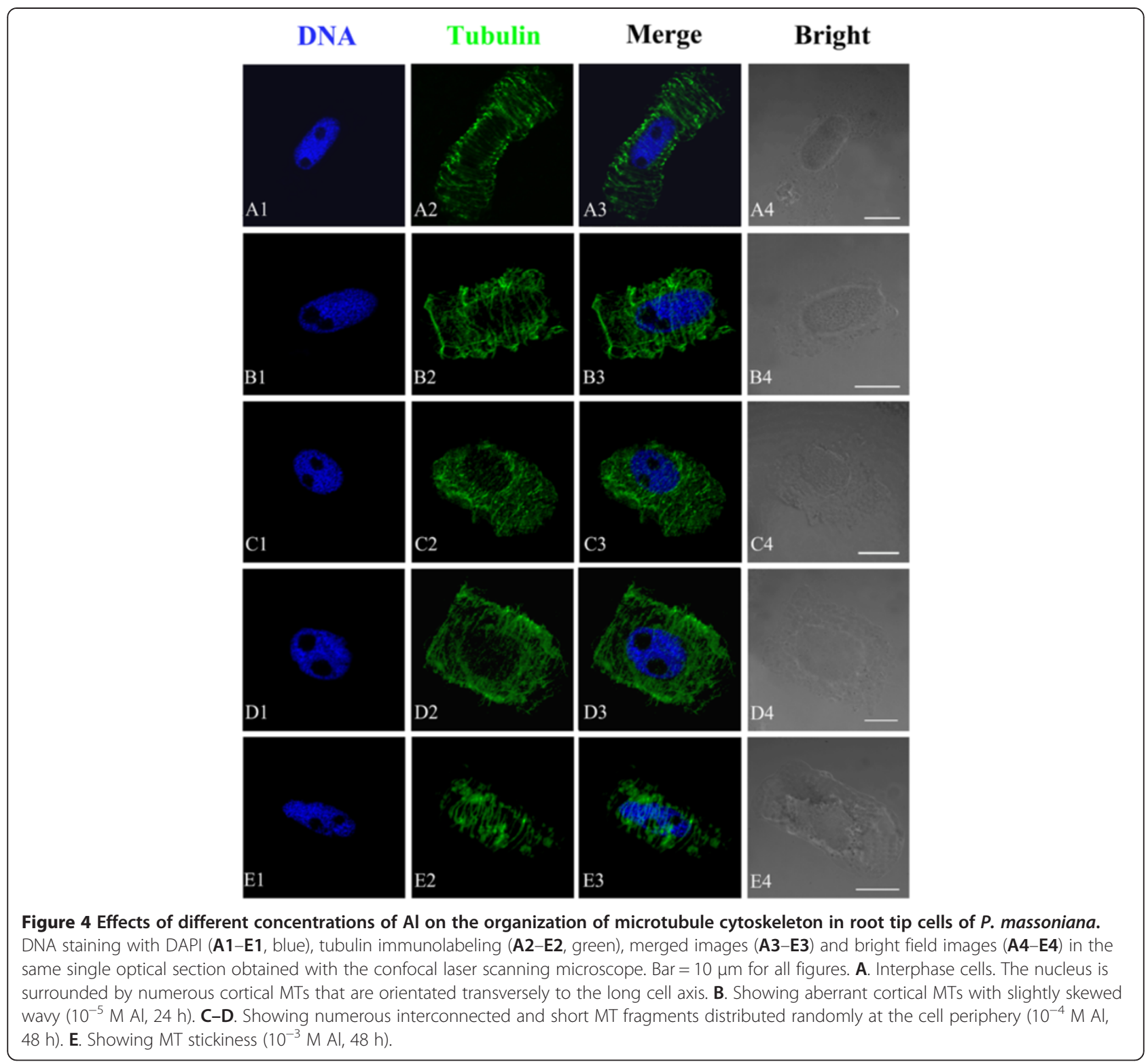

some cells. Firstly, the nucleoli were not disaggregated normally and still remained their characteristic structures during metaphase (Figure $6 \mathrm{H}-\mathrm{I}$ ) and anaphase (Figure 6J), which was called persistent nucleoli. Secondly, some small NORs were localized on sticky chromosomes and more similar silver stained particles were distributed in cytoplasm (Figure 6K-L).

\section{Effects of Al on nucleoli}

Normally, the nucleus of $P$. massoniana contains 1 to 2 nucleoli (Figure 7A). The toxic effects of $\mathrm{Al}$ on nucleoli varied with the concentration and the treatment time. At low concentration $\left(10^{-5} \mathrm{M} \mathrm{Al}\right)$, nucleoli were irregularly swollen in most of the root tip cells (Figure 7B). Some tiny particles containing argyrophilic proteins were scattered in the nucleus of root tip cells exposed to $10^{-4} \mathrm{M} \mathrm{Al}$ for $24 \mathrm{~h}$ (Figure $7 \mathrm{C}$ ). Large amounts of the tiny particulates were observed with prolonged the treatment time (Figure 7D). In Figure 7E, the particles were accumulated and leached out from the nucleus to the cytoplasm after $10^{-4} \mathrm{M} \mathrm{Al}$ treatment for $48 \mathrm{~h}$. The phenomenon was also observed in the cells exposed to $10^{-3} \mathrm{M} \mathrm{Al}$ after $72 \mathrm{~h}$ treatment. The amount of this particulate material increased progressively in cytoplasm (Figure 7F-G) and nearly occupied the whole cytoplasm when the $\mathrm{Al}$ concentration was increased to $10^{-2} \mathrm{M}$ (Figure $7 \mathrm{H}-\mathrm{J})$. In long cells, the nucleolar materials were extruded from the nucleus into the cytoplasm and gathered at the cell ends, and large rod-like structures were formed (Figure 7K). The nucleolar remains in the 


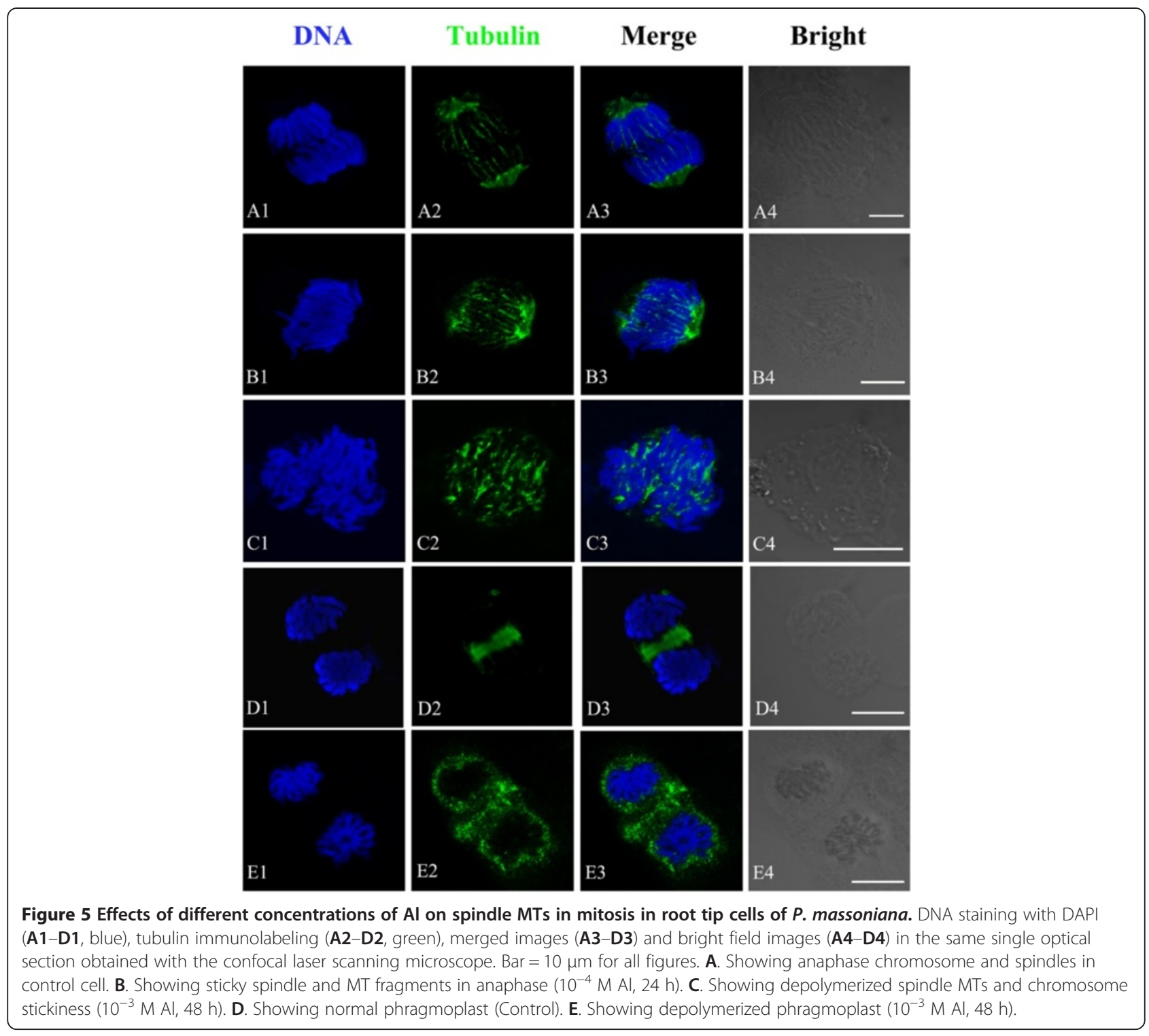

nucleus became small in size and weak in silver staining reaction (Figure 7L).

\section{Translocation of the three major nucleolar proteins in relation to Al treatment}

Immunofluorescence localizations of B23, C23 and fibrillarin were performed in the present investigation. The antibodies used could produce positive reactions with three nucleolar proteins above. There were obvious toxic effects on the three nucleolar proteins in the root tip cells of $P$. massoniana exposed $10^{-2} \mathrm{M} \mathrm{Al}$ treatment when compared with control cells.

B23 was appeared green in colour by blue light after tagging with FITC under immunofluorescent microscopy. The images in Figure 8 obtained from confocal microscopy showed that B23 signals monitored by the anti-B23 antibody were all distributed in nucleolus in control cells (Figure 8A1-A3). After $10^{-2} \mathrm{M} \mathrm{Al}$ treatment for $72 \mathrm{~h}$, firstly, B23 signals were transferred from nucleolus to nucleoplasm (Figure 8B1-B3). Then large amounts of B23 signals were observed in cytoplasm, and localized around the nucleus in varying degrees (Figure $8 \mathrm{C}-\mathrm{D}$ ).

Nucleolar protein C23 was marked with TRITC and produced red fluorescent signal under confocal microscopy. The present investigation proved that red small amount of immunofluorescence spots of C23 were scattered in nucleolus in control cells (Figure 9A1-A3). Exposure of cells to $\mathrm{Al}\left(10^{-2} \mathrm{M}\right)$ for $72 \mathrm{~h}$, the transformation of $\mathrm{C} 23$ localization was remarkable when compared with control. More C23 signals were seen in nucleoplasm, and on the way from nucleoplasm to cytoplasm (Figure 9B-C). Besides, the intensity of red fluorescent 


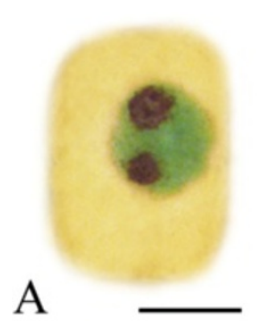

A
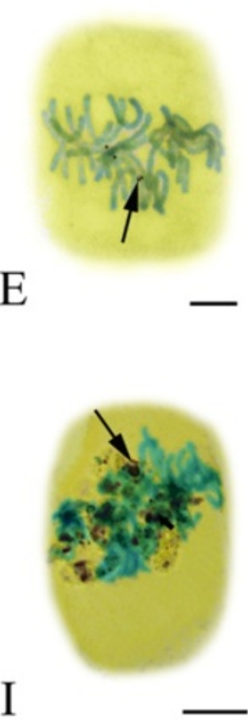

B
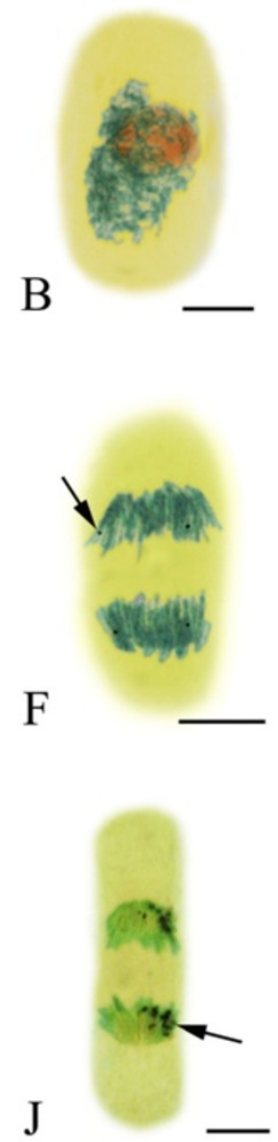

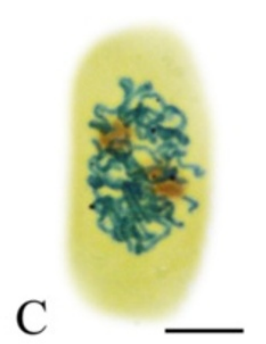

$\mathrm{C}$

$\mathrm{D}$
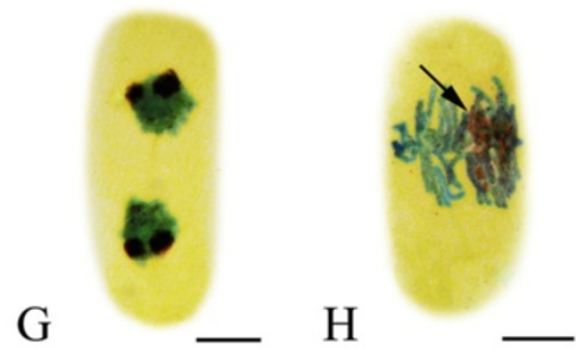

K

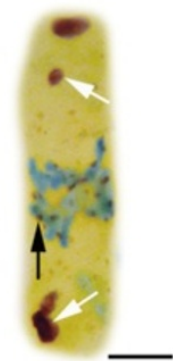

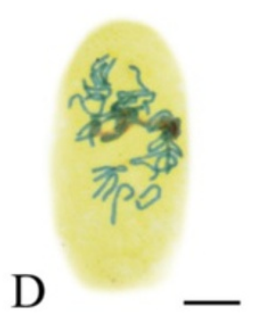

H

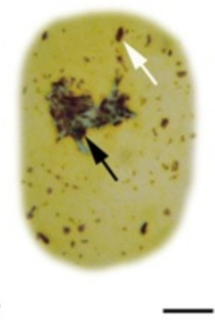

Figure 6 Effects of Al on NORs in root tip cells of $P$. massoniana during mitosis (Black arrowheads show NORs; White arrowheads show silver stained materials). A-I. Normal mitotic process. A-C. Showing decondensed chromatin fibers around the nucleoli. D. Showing decreased nucleoli in size. E. Showing filamentous NORs at late prophase. F. Showing NORs on metaphase chromosome. G. Showing NORs migration with the chromosomes to the poles at anaphase. $\mathbf{H}-\mathbf{L}$. Mitotic process under Al stress. $\mathbf{H}-\mathbf{J}$. Nucleoli still existed after the treatment with Al during metaphase ( $\mathbf{H}: 10^{-5} \mathrm{M} \mathrm{Al}, 72 \mathrm{~h}$; l: $10^{-4} \mathrm{M} \mathrm{Al}, 24 \mathrm{~h} ; \mathbf{J}: 10^{-3} \mathrm{M} \mathrm{Al}, 24 \mathrm{~h}$ ). K-L. Showing some small NORs localized on sticky chromsomes and similar silver stained particles distributed in cytoplasm (K: $10^{-4} \mathrm{M} \mathrm{Al}, 72 \mathrm{~h} ; \mathrm{L}: 10^{-3} \mathrm{M} \mathrm{Al}, 72 \mathrm{~h}$ ). Scale bar $=10 \mu \mathrm{m}$.

signal increased in cytoplasm after the treatment with Al (Figure 9D1-D3). The phenomenon was similar to the results of B23.

Nucleolar protein fibrillarin was also observed using the green fluorescent signal. Normally, green fluorescent signals of fibrillarin appeared in nucleolus in control cells of $P$. massoniana (Figure 10A1-A3). In comparison with control cells, fibrillarin was transferred from nucleolus to nucleoplasm (Figure 10B1-B3), and in some cells it was moved from nucleoplasm to cytoplasm (Figure 10C1-C3) after the treatment of $10^{-2} \mathrm{M} \mathrm{Al}$. Moreover, a great number of bigger green fluorescence spots were scattered in cytoplasm and accumulated around the nucleus (Figure 10D1-D3).

\section{Expression of the three major nucleolar proteins in relation to Al treatment}

The contents of the three major nucleolar proteins (B23, fibrillarin and $\mathrm{C} 23$ ) in root tip cells of $P$. massoniana L. exposed to $10^{-2} \mathrm{M} \mathrm{Al}$ for $72 \mathrm{~h}$ were examined by western blotting, raised with specific antibodies. The evidences indicated that levels of the three examined proteins augmented significantly $(P<0.05)$ in comparison with control (Figure 11). The increase of $\mathrm{C} 23$ was the most obvious and fibrillarin and B23 were less significant. The phenomena were consistent with the results obtained from indirect immunofluorescent microscopy.

\section{Discussion}

Al uptake and its effects on mineral elements

Data from the present investigation showed $\mathrm{Al}$ was poorly translocated from roots to leaves and stems in $P$. massoniana and accumulated in its leaves and stems much less in $10^{-5} \mathrm{M}$ to $10^{-3} \mathrm{M} \mathrm{Al}$ treatment groups, but it accumulated significantly in them exposed to $10^{-2} \mathrm{M}$ Al (Table 1). P. massoniana survived as far as it was able to avoid $\mathrm{Al}$ accumulation in the shoots. Species and genotypes within species greatly differ in their tolerance 


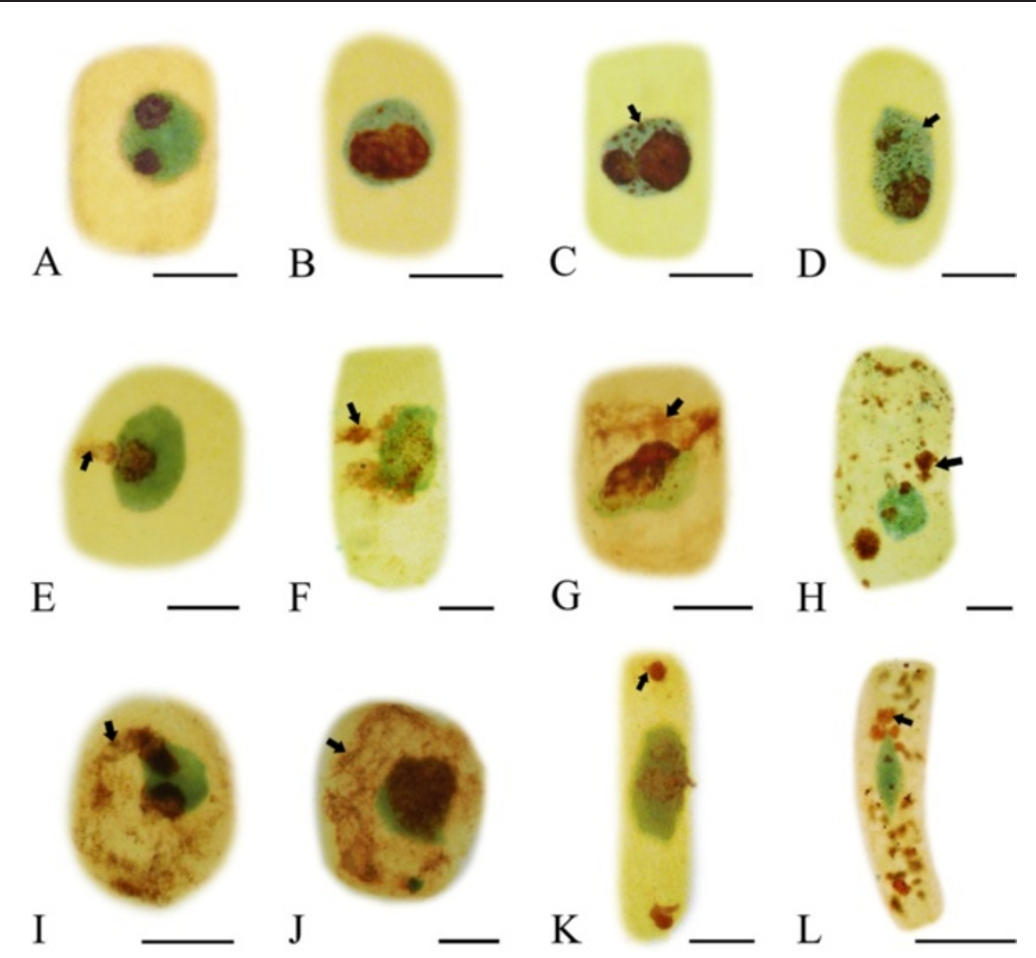

Figure 7 Effects of different concentrations of Al on nucleoli in root tip cells of $P$. massoniana. Arrowhead shows argyrophilic proteins. A. Control cells. B. Showing the irregular nucleolus $\left(10^{-5} \mathrm{M} \mathrm{Al}, 72 \mathrm{~h}\right)$. C. Some particles containing argyrophilic proteins scattered in the nucleus $\left(10^{-4} \mathrm{M} \mathrm{Al}, 24 \mathrm{~h}\right)$. D. Large amounts of argyrophilic proteins in nucleus with prolonging treatment time $\left(10^{-4} \mathrm{M} \mathrm{Al}, 48 \mathrm{~h}\right)$. E-G. Argyrophilic proteins leaching from the nucleus to the cytoplasm and more and more argyrophilic proteins accumulated in the cytoplasm with prolonging the duration of treatment ( $\mathbf{E} \cdot 10^{-4} \mathrm{M} \mathrm{Al}, 48 \mathrm{~h} ; \mathbf{F}-\mathbf{G} .10^{-4} \mathrm{M} \mathrm{Al}, 72 \mathrm{~h}$ ). $\mathbf{H}-\mathbf{J}$. Showing the argyrophilic proteins enclosed the nucleus, and accumulated in the cytoplasm and occupied nearly the whole cytoplasm (H. $\left.10^{-3} \mathrm{M} \mathrm{Al}, 72 \mathrm{~h} ; \mathbf{I} .10^{-2} \mathrm{M} \mathrm{Al}, 72 \mathrm{~h} ; \mathbf{J} .10^{-2} \mathrm{M} \mathrm{Al}, 72 \mathrm{~h}\right)$. K. In long cells, the argyrophilic proteins gathered at the cell ends $\left(10^{-2} \mathrm{M} \mathrm{Al}, 24 \mathrm{~h}\right)$. L. Argyrophilic proteins scattered in the nucleus, appearing small in size and weak in silver staining reaction $\left(10^{-2} \mathrm{M} \mathrm{Al}, 24 \mathrm{~h}\right)$. Scale bar $=10 \mu \mathrm{m}$.

to $\mathrm{Al}$ [2]. Osaki et al. [20] indicated that some species, especially those native to acidic soils, had shown enhanced growth in the presence of $\mathrm{Al}$, often coinciding with increased leaf phosphorus (P) concentrations. It was reported that $\mathrm{Al}$ was essential for the growth of Melastoma malabathricum [21]. Jansen et al. [10] proposed that plants with more than $1000 \mathrm{mg}$ Al per kg dry weight in their leaf tissues be termed hyperaccumulators. According to the results here, P. massoniana cannot be considered as a hyperaccumulator, althrough the $\mathrm{Al}$ content of leaf tissues exposed to $10^{-2} \mathrm{M} \mathrm{Al}$ reached the hyperaccumulator standard. The seedling growth of $P$. massoniana was severely inhibited under $10^{-2} \mathrm{M} \mathrm{Al}$ stress. P. massoniana treated with $10^{-5}$ to $10^{-3} \mathrm{M} \mathrm{Al}$ did accumulate $\mathrm{Al}$ in stems and leaves, but could not absorb and accumulate large amounts of $\mathrm{Al}$ (Table 1).

Magnesium (Mg) is pivotal for activating a large number of enzymes; hence, $\mathrm{Mg}$ plays an important role in numerous physiological and biochemical processes affecting plant growth and development [22]. The results indicated that the contents of $\mathrm{Mg}$ and iron $(\mathrm{Fe})$ in stems of $P$. massoniana seedlings increased and decreased in roots with increasing $\mathrm{Al}$ (Table 2). Al-induced $\mathrm{Mg}$ deficiency in roots may be explained by the fact that the $\mathrm{Al}$ and $\mathrm{Mg}$ ions compete for membrane transporters and metalbinding sites on enzymes [23], as $\mathrm{Al}$ and $\mathrm{Mg}$ ions have similar hydrated radius [24]. As a result, $\mathrm{Mg}$ ion bind relatively weakly to the negatively charged groups in the root cell wall, so the excess cations such as $\mathrm{H}^{+}$and $\mathrm{Al}^{3+}$ present in acid soils can inhibit $\mathrm{Mg}^{2+}$ loading into the apoplasm and uptake across the plasma membrane [25]. After uptake, Mg must be released to the xylem for translocation from the roots to the shoots. In the present investigation, $\mathrm{Mg}$ content in stems of $P$. massoniana seedlings increases. However, transporters for this process have not been identified. Chen and Ma [26] indicated that based on the RiceXPro database, two CorA-like homologues in rice show high expression in the vascular tissue of root elongation and maturation zones, suggesting their possible role in $\mathrm{Mg}$ xylem loading. The transporters for xylem unloading have also not been identified.

Reports on the effects of $\mathrm{Al}$ on uptake of manganese (Mn) are conflict (Table 2). Alam [27] indicated that Al 


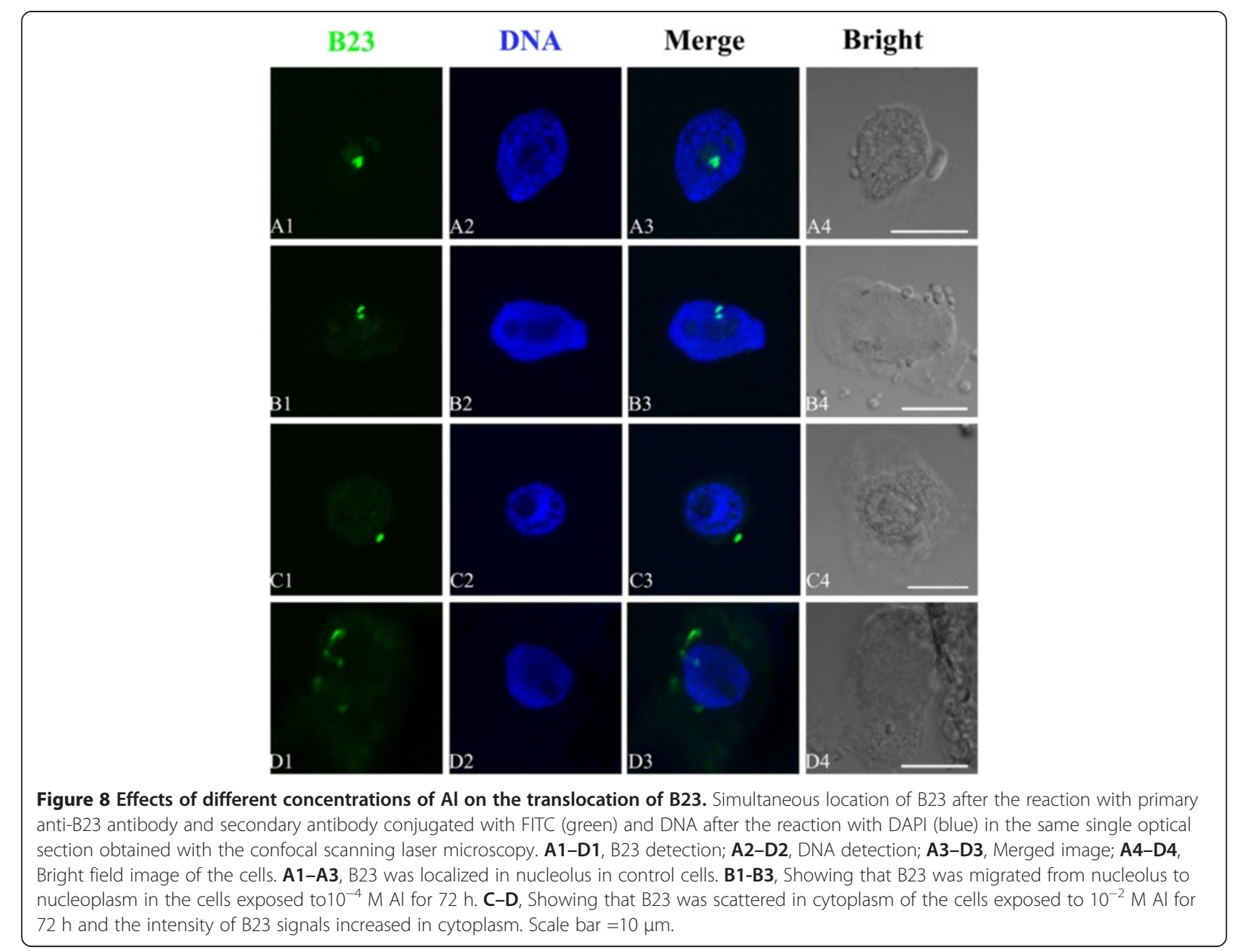

could decrease the concentration of $\mathrm{Mn}$ in all parts of barley plants except stem, where more Mn concentration was recorded. However, in rice, Mn concentration decreased in plant tops but increased in roots with increasing $\mathrm{Al}$, suggesting that $\mathrm{Mn}$ may compete effectively with A1 for root absorption sites [28]. Mariano and Keltjens [29] found that all 10 maize genotypes absorbed $\mathrm{Mn}$ in amounts significantly lower than their control plants grown in the absence of Al. These conflicting results arise, in part, from the genetic material used. Data from the present investigation showed that uptake and accumulation of $\mathrm{Mn}$ in the organs were inhibited significantly $(P<0.05)$ under $\mathrm{Al}$ stress. The results here indicated that the content of Fe in stems of P. massoniana seedlings increased with increasing $\mathrm{Al}$, which is consistent with the findings of Alam [28] and Guo et al. [30].

\section{Toxic effects of Al on cell division}

The inhibition of root elongation is the first visible symptom of $\mathrm{Al}$ toxicity, although the response of the roots to Al toxicity differs among plant species and even cultivars.
In the present study, $\mathrm{Al}$ had an inhibitory effect on the root growth at all concentrations $\left(10^{-5}-10^{-2} \mathrm{M}\right)$ used during the entire treatment (72 h) (Figures 1 and 2), suggesting that root cells is a primary target of $\mathrm{Al}$ toxicity. The dissociation of the metallic salt $\mathrm{AlCl}_{3}$ altered the ionic environment of the cell, which might have led to a physiological change in the nucleoprotein or denaturation of proteins reflected as chromosomal aberrations [31]. Some reports indicated that in sensitive plants, cell division in the root tip meristem was quickly inhibited by $\mathrm{Al}$, resulting in affecting root elongation immediately [32-34].

Chromosome aberrations have been used as a measure of reproductive success and as a method for the detection of possible genetic damage by environmental agents (such as herbicides, insecticides, fungicides and heavy metals) in plants for many years, and can provide both qualitative and quantitative data on the effects [35]. Cytogenetic analysis has also revealed the presence of abnormally dividing cells. Our cytological observations clearly showed that $\mathrm{Al}$ had toxic effects on the cell 


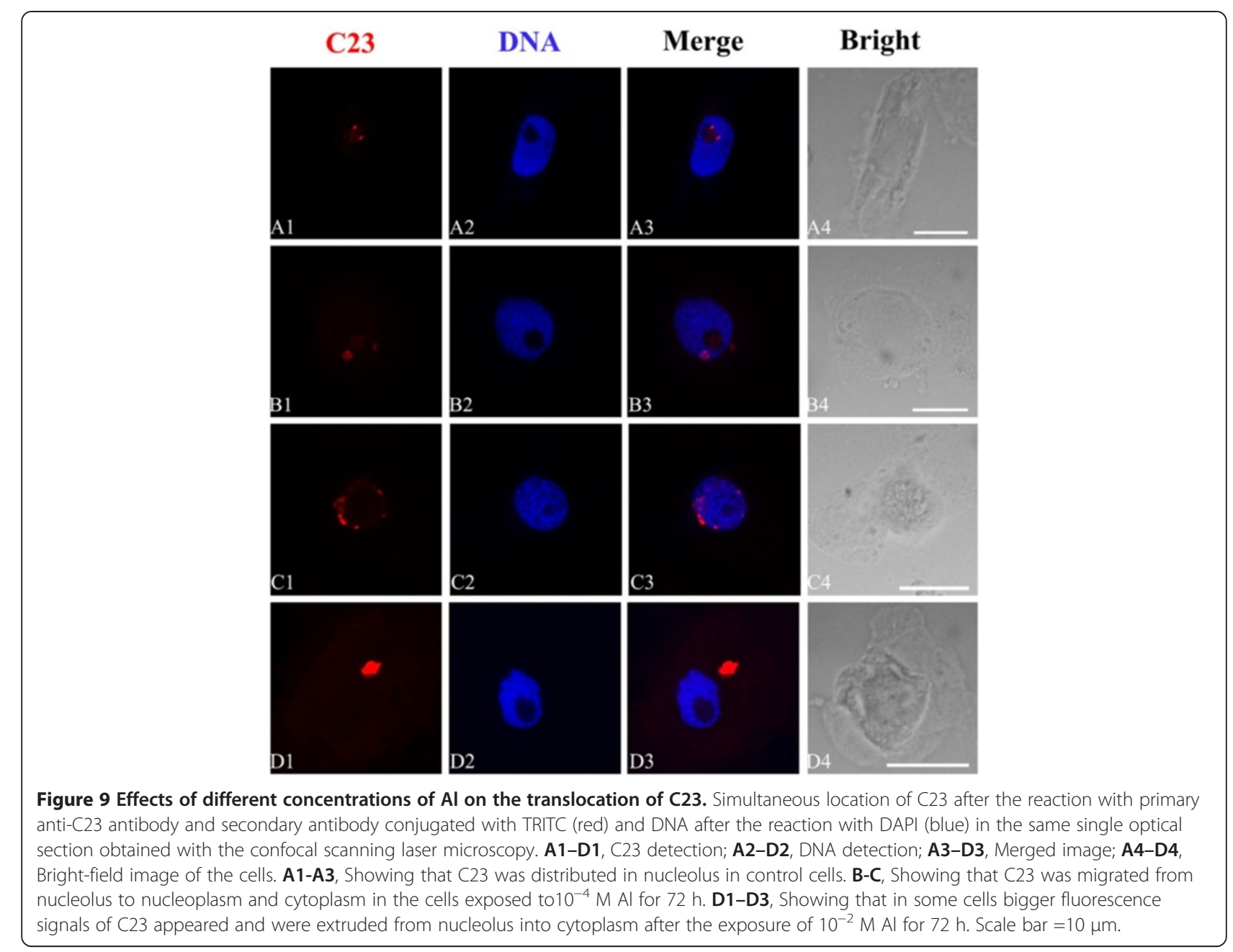

division and induced the four types of chromosomal aberrations, chromosome fragments, chromosome bridges, C-mitosis and chromosome stickiness (Figure 3), which is similar to previous reports described by Liu et al. [36]. The chromosome bridges exhibiting stickiness was found in the present study, which was in agreement with other reports where $\mathrm{Al}, \mathrm{Cd}$ and $\mathrm{Cr}(\mathrm{VI})$ on root tip cell division of Oryza sativa [31], Allium cepa [37] and Amaranthus viridis [38] were investigated. Some studies concerning with the reasons for the formation of stickiness of chromosomes have been reported, such as the increased chromosome contraction and condensation [39], the depolymerization of DNA [40] and partial dissolution of nucleoproteins [41]. This kind of chromosomal aberration, usually being irreversible, reflects highly toxic effects and probably leads to cell death. C-mitosis, first described by Levan [42] in the root tip mitosis of Allium cepa as an inactivation of the spindle followed by random scattering of the condensed chromosomes. The c-metaphase we observed in the treated meristems suggests that $\mathrm{Al}$ acts on the mitotic spindle apparatus, probably interfering with the polymerization and depolymerization of microtubules [43]. Chromosome bridges or interchromatid connections are formed by chromatin fibers that join sister chromatids at metaphase and hold the chromatids together until late anaphase or telophase. If these connections become too strong, chromatids might break at or near the points of connection at anaphase. These breaks occurred here at the same point in the sister chromatids, giving rise to fragments of chromosome-like structure $[31,39]$.

It seems reasonable to suggest that $\mathrm{Al}$ is either affecting indirectly some metabolic process associated with cell division, or that it has its effect during DNA replication in interphase [32]. Al has been found to inhibit cell division and to be associated with DNA in several plants $[44,45]$. Matsumoto indicated that one toxic function of $\mathrm{Al}$ in rapidly growing pea roots was the binding of $\mathrm{Al}$ to DNA regions unmasked with chromosomal proteins in nuclei causing the condensation and stabilization of chromatin structure and thereby reducing the template activity. Thus, cell division at root tips is inhibited by $\mathrm{Al}$ 

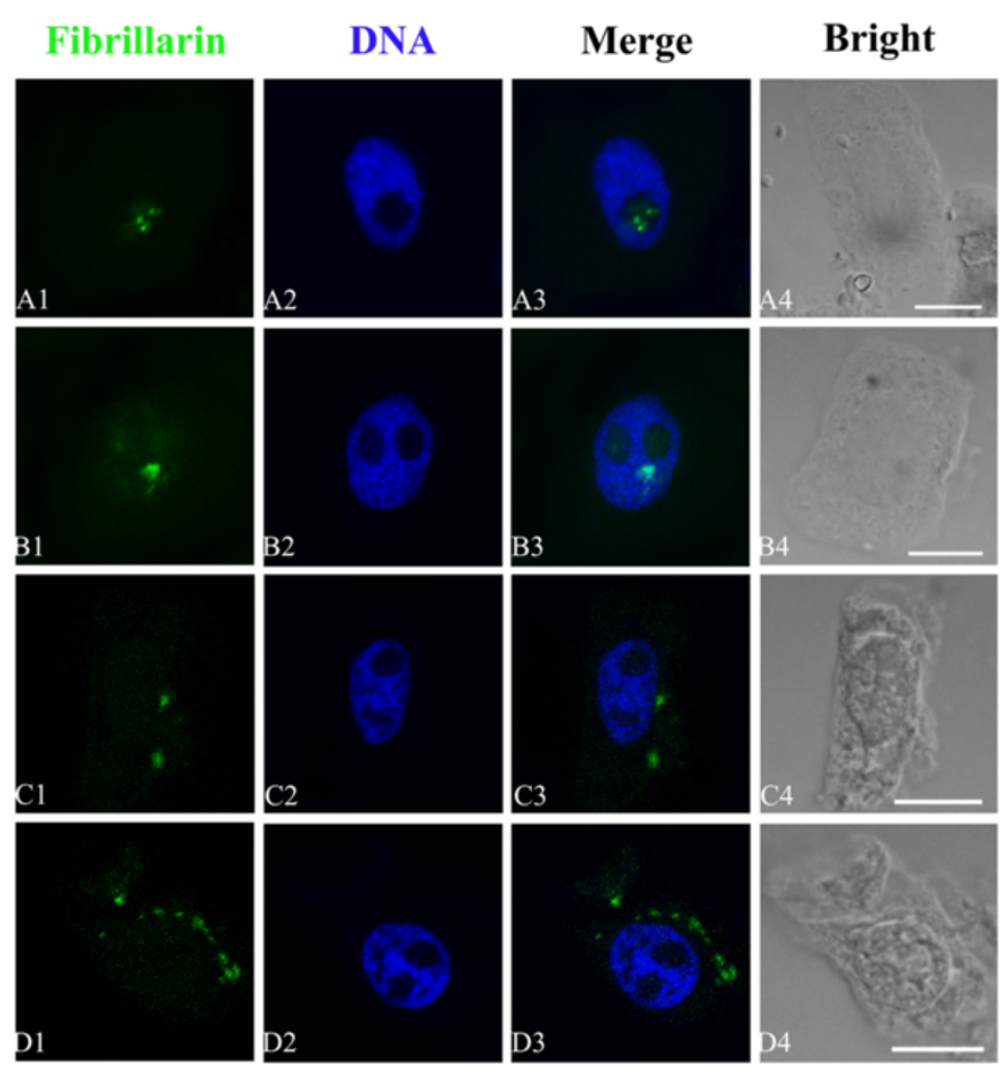

Figure 10 Effects of different concentrations of Al on the translocation of fibrillarin. Simultaneous location of fibrillarin after the reaction with primary anti-fibrillarin antibody and secondary antibody conjugated with FITC (green) and DNA after the reaction with DAPI (blue) in the same single optical section obtained with the confocal scanning laser microscopy. A1-D1, Fibrillarin detection; A2-D2, DNA detection; A3-D3, Merged image; A4-D4, Bright-field image; A1-A3, Showing that fibrillarin was localized in nucleolus in control cells. B1-B3, Showing that fibrillarin was transferred from nucleolus to nucleoplasm in the cells treated with $10^{-4} \mathrm{M}$ Al for $72 \mathrm{~h}$. C1-C3, Showing that fibrillarin was on the way from nucleus to cytoplasm in the cells treated with $10^{-2} \mathrm{M}$ Al for $72 \mathrm{~h}$. D1-D3, Showing that larger amount of fluorescence signals of fibrillarin appeared and was transferred from nucleolus to cytoplasm in the cells exposed to $10^{-2} \mathrm{M} \mathrm{Al}$ for $72 \mathrm{~h}$. These signals were close to nucleus and accumulated around the nucleus in varying degrees. Scale bar $=10 \mu \mathrm{m}$.

toxicity [46]. Recent studies have demonstrated that $\mathrm{Al}$ toxicity is associated with mitochondrial dysfunction and the production of reactive oxygen species (ROS) in plant cells $[47,48]$. The attack of ROS to purine-, pyriminidebases, and deoxyribose in DNA can cause DNA single and double strand breaks, which may increase the probability of chromosomal aberrations formation.

MTs, one key components of the eukaryotic cytoskeleton, play a central role in diverse activities such as cell division, cell expansion, cell differentiation and intracellular organization and motility $[49,50]$. Cytoskeletal network of plant cell is formed by the integrated arrays of MTs, actin filaments, intermediate filaments, microtubule- and actin-related proteins and others [51,52]. Al, in micromolar concentrations, delays microtubule (MT) reorganization and MT-mediated chromosome movement during mitosis in the root tip cells of Triticum turgidum $[53,54]$. Frantzios et al. reported that $\mathrm{Al}$ affected the mechanisms controlling the organization of the microtubule cytoskeleton as well as tubule polymerization, which delayed microtubule disassembly during mitosis, resulting in the disorder of chromosome movements carried out by the mitotic spindle [53]. The findings of this study showed that the $\mathrm{Al}$ ions directly or indirectly affected the dynamic condition of MTs and disturbed the organization and function of the mitotic apparatus, resulting in disordering or inhibition of chromosome movement. Al induced the formation of abnormal microtubule (MT) arrays, consisting of discontinuous wavy MTs or short MT fragments at the cell periphery (Figure 4). With increased $\mathrm{Al}$ concentration and prolonged duration of treatment, MT organization and function of the mitotic spindle and phragmoplast were severely disturbed (Figure 5). This study revealed that the MT cytoskeleton was a target site of $\mathrm{Al}$ toxicity in mitotic roottip cells of $P$. massoniana. The structural changes have been attributed to depolymerization of the cortical MTs or to extensive cell-specific depolymerization or to reorganization and stabilization of MTs and actin filaments [55]. 


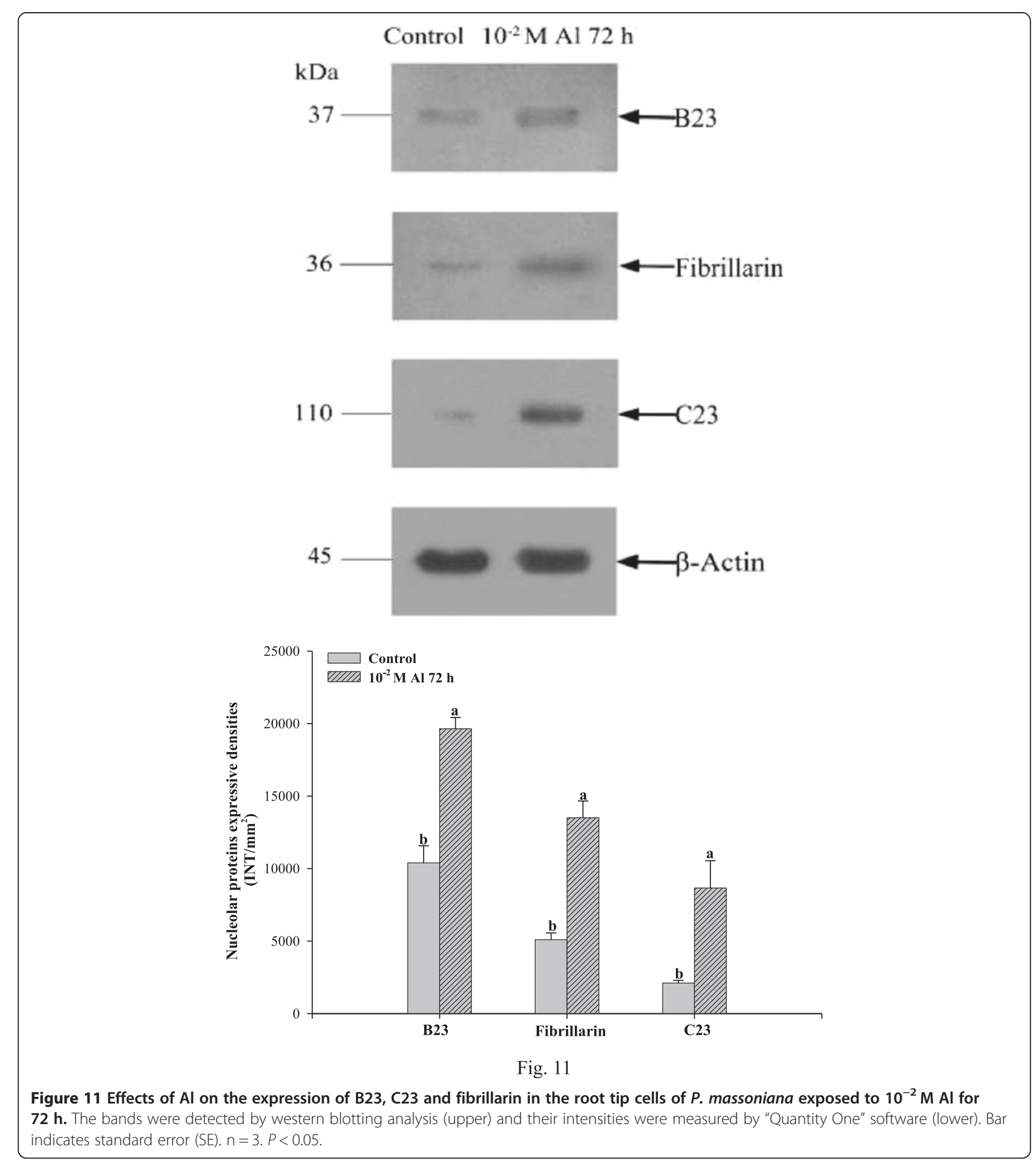

In this investigation, the contents of $\mathrm{Mg}$ decreased in roots with increasing $\mathrm{Al}$. Al transport through the $\mathrm{Mg}$ channel is also likely because $\mathrm{Mg}$ transport is strongly inhibited by $\mathrm{Al}$ due to the similar diameter of $\mathrm{Al}$ and $\mathrm{Mg}$ [56]. Al can bind to nucleoside triphosphates approximately $10^{7}$ times better than $\mathrm{Mg}$, and the rate of hydrolysis for Al-ATP or Al-GTP complexes is considerably lower than that for the physiological $\mathrm{Mg}$ complex ( $10^{5}$ times slower), supporting the hypothesis that toxicity is a result of $\mathrm{Al}$ ions displacement of $\mathrm{Mg}$ ions from nucleoside di- or triphosphate complexes [57]. As the replacement of $\mathrm{Mg}$ ions by $\mathrm{Al}$ ions during tubulin polymerization in vivo, MTs with atypical properties may be formed [58]. 


\section{Toxic effects of $\mathrm{Al}$ on nucleoli}

The silver staining technique has been widely applied in cytological studies aimed at understanding the nucleolar cycle and nucleolar organization in both animals and plants. NORs are defined as nucleolar components containing a set of argyrophilic proteins, which are selectively stained by silver methods $[59,60]$. Changes of argyrophilic proteins in nucleoli can be showed specifically using silver staining method. Evidence from the present investigation revealed that the nucleolar material in some root tip cells did not completely disappear during metaphase under $\mathrm{Al}$ stress (Figure 6), which was similar to the phenomenon observed by Qin et al. [61]. Generally, persistent nucleoli do not occur during normal mitosis. Vostrikova and Butorina [62] indicated an increased number of persistent nucleoli cells increased nucleolar activity. Sheldon et al. [63] studied a series of embryonal carcinoma lines and found them to exhibit nucleolar persistence during mitotic metaphase and anaphase, supposing that rRNA synthesis continues in persistent nucleoli, which means increased biosynthetic activity and more protein production. It was reported that the birch seedling in response to anthropogenic stress (heavy metals, smoke, dust et al.) revealed persistent nucleolus in some cells during mitotic metaphase [62]. It was demonstrated that $\mathrm{Cd}$ and $\mathrm{Cr}$ (VI) could induce persistent nucleoli in root tips of Vicia faba [64] and Allium cepa [37]. Thus, it may be hypothesized that the phenomenon persistent nucleolus is an adaptive response to stress induced by $\mathrm{Al}$.

The Al-induced phenomena observed in this work were that some tiny particles containing argyrophilic proteins were scattered in the nucleus of root tip cells and leached out from the nucleus to the cytoplasm (Figure 7). These effects of $\mathrm{Al}$ on nucleoli are more or less the same as those reported by Fiskesjö [65,66], Liu and Jiang [67], Zhang et al. [64] and Qin et al. [61]. However, they did not indicate what kinds of proteins involved in those reports. The recent studies reported that the argyrophilic proteins were B23 and C23 in Allium cepa [68] and in Hordeum vulgare (unpublished) by indirect immunofluorescence and western blotting. Evidence in this investigation indicated that $\mathrm{Al}$ could induce the three proteins extruded from nucleoli to cytoplasm (Figures 8, 9 and 10), which confirmed the findings reported by Qin et al. [68]. The nucleolus is the most prominent substructure in the cell nucleus, which is a very dynamic structure and form around the rDNA loci [69]. It plays important roles in the regulation of many fundamental cellular processes, including cell cycle regulation, apoptosis, telomerase production, RNA processing, monitoring and response to cellular stress [70,71]. B23 and C23 belong to the two major AgNOR proteins [72,73]. However, fibrillarin is distinguished from them by its lack of affinity for silver staining [74]. It has a molecular mass of $41 \mathrm{kDa}$ and is present both in animal and plant cells and is required for multiple events leading to rRNA maturation and ribosome subunit assembly [75]. So we suggest that $\mathrm{Al}$ may also have toxic effects on other kinds of nucleolar proteins besides argyrophilic and acidic nucleolar proteins. More studies, however, are required in this direction.

Western blot analysis of the expression of the three proteins showed that $\mathrm{Al}$ could induce significant bulking of expression (Figure 11). The changes of localization and expression of the three proteins can be used as valuable and early markers in cellular changes induced by $\mathrm{Al}$ for the evaluation of metal contamination. Nevertheless, more studies including the interaction of nucleolus proteins and the molecular mechanism of $\mathrm{Al}$ stress will be required to be clarified.

\section{Conclusion}

Based on the information provided in this article, it is concluded that (1) The accumulation of $\mathrm{Al}$ ions primarily was in roots of $P$. massoniana, and small amounts of $\mathrm{Al}$ were transported to aboveground. (2) Al could disturb cell division inducing chromosome aberration. (3) In the presence of $\mathrm{Al}$, the abnormal MT arrays were formed, and MT organization and function of the mitotic spindle and the phragmoplast were severely disturbed. (4) Persistent nucleoli existed during metaphase. (5) Al could affect nucleoli, inducing nucleolar particles containing argyrophilic proteins leached out from the nucleus to the cytoplasm. (6) Evidence confirmed that these proteins were B23, C23 and fibrillarin. (7) Al could induce overexpression of the three major nucleolar proteins.

\section{Methods}

\section{Al determination}

\section{Culture condition and $\mathrm{Al}$ treatment}

Healthy and equal-sized seeds were chosen from $P$. massoniana. The seeds were soaked in tap water for $48 \mathrm{~h}$. Then, they were transferred to a tray lined with wet gauze and germinated in light incubator at $26^{\circ} \mathrm{C}$. The seedlings with about $4.5 \mathrm{~cm}$ were grown in containers with 2 L Hoagland's nutrient solution ( $\mathrm{pH} 4.0)$ adding different concentrations of $\mathrm{Al}$ solutions $\left(10^{-5}, 10^{-4}, 10^{-3}\right.$ and $10^{-2} \mathrm{M}$ ) for $40 \mathrm{~d}$ respectively in a greenhouse where relative humidity (60\%) and supplementary lighting (14 h photoperiod) were controlled. The $\mathrm{Al}$ was provided as aluminum chloride $\left(\mathrm{AlCl}_{3}\right)$. The $\mathrm{Al}$ solutions were prepared in deionized water, and were added to the modified half Hoagland's nutrient solution [61] containing $5 \mathrm{mM}$ $\mathrm{Ca}\left(\mathrm{NO}_{3}\right)_{2}, 5 \mathrm{mM} \mathrm{KNO}, 1 \mathrm{mM} \mathrm{KH} \mathrm{PO}_{4}, 1 \mathrm{mM} \mathrm{MgSO}$, $50 \mu \mathrm{M} \mathrm{H}_{3} \mathrm{BO}_{3}, 10 \mu \mathrm{M}$ FeEDTA, $4.5 \mu \mathrm{M} \mathrm{MnCl} \mathrm{Mn}_{2}, 3.8 \mu \mathrm{M}$ $\mathrm{ZnSO}_{4}, 0.3 \mu \mathrm{M} \mathrm{CuSO}$, and $0.1 \mu \mathrm{M}\left(\mathrm{NH}_{4}\right)_{6} \mathrm{Mo}_{7} \mathrm{O}_{24}$ $(\mathrm{pH}=4.0)$. The half Hoagland's nutrient solution without Al was used for control plants. The solutions were aerated by pumps, which connected the containers 
with pump lines. The nutrient solutions were changed regularly every 10 days. The seedlings from each treatment were harvested after $40 \mathrm{~d}$ of incubation for $\mathrm{Al}$ determination.

\section{Sampling procedure and Al determination}

Ten seedlings from each treatment and control were harvested based on uniformity of size and colour (removing the greatest and the smallest seedlings and then selected randomly) at the end of each time interval (10 d). The seedlings were removed from solution and washed thoroughly with running tap water for $30 \mathrm{~min}$ and then with deionized water to remove traces of nutrients and $\mathrm{Al}$ ions from root surfaces. Seedlings were divided into roots, leaves and stems. The samples were dried to a constant weight (for $3 \mathrm{~d}$ at $45^{\circ} \mathrm{C}$, for $1 \mathrm{~d}$ at $80^{\circ} \mathrm{C}$, and for $12 \mathrm{~h}$ at $105^{\circ} \mathrm{C}$ ). All dried plant samples were prepared using a wet-digestion method [62]. The contents of $\mathrm{Al}, \mathrm{Mg}, \mathrm{Mn}$ and Fe were determined with inductively coupled plasma atomic emission spectrometry (ICP-AES) (Leeman Labs Inc., New Hampshire, USA) after dry-ashing [63].

\section{Cytological study Culture condition and Al treatment}

Healthy and equal-sized seeds were chosen from $P$. massoniana. The seeds were soaked in tap water for $48 \mathrm{~h}$ before starting the experiment. Then they were transferred to plastic containers, which in the bottom has wet gauze to germinate at $26^{\circ} \mathrm{C}$ for several days. Then the roots reaching about $0.6 \mathrm{~cm}$ length were treated in Petri dishes with different concentrations of $\mathrm{Al}$ solutions $\left(10^{-5}\right.$ to $10^{-2} \mathrm{M}$ ) for 24,48 and $72 \mathrm{~h}$. The test liquids were changed regularly every $24 \mathrm{~h}$. Control roots were maintained in distilled water. The $\mathrm{Al}$ was provided as aluminum chloride $\left(\mathrm{AlCl}_{3}\right)$. The length of roots were observed, measured and recorded at the end of each time interval (324 h).

\section{Staining method}

Ten root tips from control and seedlings of $P$. massoniana treated with $\mathrm{Al}$ were cut and fixed in 3 parts $95 \%$ ethanol: 2 parts acetic acid for $2 \mathrm{~h}$ and hydrolyzed in 5 parts $1 \mathrm{M}$ hydrochloric acid: 3 parts 95\% ethanol: 2 parts $99.8 \%$ acetic acid for $10 \mathrm{~min}$ at $60^{\circ} \mathrm{C}$. For the observation of changes in cell division, ten root tips were squashed in Carbol Fuchsin solution [64]. For the observation of changes in nucleolus, ten root tips were cut and squashed in $45 \%$ acetic acid, dried, and after 2 days stained with silver nitrate [53].

\section{Indirect immunofluorescent microscopy}

Meristematic zones of root tips from control and seedlings of $P$. massoniana treated with $\mathrm{Al}$ were cut and fixed with $4 \%(\mathrm{w} / \mathrm{v})$ paraformaldehyde in phosphate-buffered saline
(PBS, pH 7.0) for $1.5 \mathrm{~h}$ in darkness at room temperature and then they were washed with the same buffer. Meristematic cells were digested with a mixture of $2.5 \%$ cellulose and $2.5 \%$ pectolase at $37^{\circ} \mathrm{C}$ and then washed in PBS for three times. They were squashed on slides and extracted in freshly prepared $1 \%(\mathrm{v} / \mathrm{v})$ Triton X-100 in PBS when slides dried. After three washings in PBS, the cells were subsequently incubated with mouse primary antibodies respectively against B23, fibrillarin, C23 or tubulin for $1 \mathrm{~h}$ at $37^{\circ} \mathrm{C}$ or at $4^{\circ} \mathrm{C}$ overnight in a moist, sealed chamber. After washing $(3 \times 10 \mathrm{~min})$ in PBS, the cells were incubated with secondary antibodies for detection of the primary antibodies for $45 \mathrm{~min}$ in darkness at $37^{\circ} \mathrm{C}$. After repeated washing in PBS, nuclei were stained with 4', 6-diamidino-2-phenylindole (DAPI, Sigma) at a final concentration of $1 \mathrm{ug}$ per $1 \mathrm{ml}$ for $15 \mathrm{~min}$ at room temperature. After washing $(3 \times 10 \mathrm{~min})$ in PBS, the cells were mounted in antifade mounting medium. The slides were stored at $4^{\circ} \mathrm{C}$ in the dark until observed. The immunofluorescent specimens were examined with a Nikon ECLIPSE 90i confocal laser scanning microscope. An exciter at $488 \mathrm{~nm}$ and a barrier at 590/50 nm, an exciter at $543 \mathrm{~nm}$ and a barrier at $650 \mathrm{~nm}$, and an exciter at $408 \mathrm{~nm}$ and a barrier at 515/30 nm were used for FITC, TRITC and DAPI staining, respectively. Image recording was done with proper software (EZ-C1 3.80) according to the manufacturer's instructions. Images were processed with Image-Pro Plus 6.0 and Photoshop CS3.

Antibodies used in this study were as follows:

- B23: primary antibody: a mouse monoclonal antibody to B23 (Sigma, B0556) at dilution 1:100; secondary antibody: FITC-conjugated goat antimouse IgGs (Sigma, F9137) at dilution 1:50. FITC was used for the detection of signal.

- Fibrillarin: primary antibody: a mouse monoclonal antibody to fibrillarin (Santa, SC-81273) at dilution 1:100; secondary antibody: FITC-conjugated goat anti-mouse IgGs (Sigma, F9137) at dilution 1:50. FITC was used for the detection of signal.

- C23: primary antibody: a mouse monoclonal antibody to C23 (Santa, SC-8031) at dilution 1:100; secondary antibody: TRITC-conjugated goat antimouse IgGs (Sigma, T5393) at dilution 1:50. TRITC was used for the detection of signal.

- Microtubulin: primary antibody: mouse monoclonal anti-a-tubulin antibody (Sigma T-9026) at diluted at 1:100: secondary antibody: FITC-conjugated goat anti-mouse IgGs (Sigma, F9137) at dilution 1:50. FITC was used for the detection of signal.

\section{Western blotting}

Root tips from control and seedlings treated with $10^{-2} \mathrm{M}$ $\mathrm{Al}$ for $72 \mathrm{~h}$ were homogenized respectively in a pestle and 
mortar with liquid nitrogen and then the samples were solubilized with chilled extraction buffer $(50 \mathrm{mM}$ Tris-HCl (pH 7.8), $10 \mathrm{mM} \mathrm{MgCl}_{2}, 20 \mathrm{mM} \quad \beta-$ mercaptoethanol, $1.0 \mathrm{mM}$ EDTA, $8 \%$ glycerol) adding protease inhibitor cocktail set VI (Merck, 539133). After vortexing for $1 \mathrm{~min}$ at room temperature, the homogenates were kept on ice for $30 \mathrm{~min}$, and then centrifuged at $12,000 \mathrm{rpm}$ at $4^{\circ} \mathrm{C}$ for $5 \mathrm{~min}$. The mixture of supernatant and $1 \times$ laemmli buffer $(62.5 \mathrm{mM}$ Tris $-\mathrm{HCl}$ (pH 6.8), 5\% $\beta$-mercaptoethanol, 2\% SDS, 10\% glycerol, $0.001 \%$ bromophenol blue) was boiled at $100^{\circ} \mathrm{C}$ for 5 min [65] and then was subjected to $12 \%$ SDS-PAGE electrophoresis and the separated proteins were wet blotted onto $0.45 \mu \mathrm{m}$ PVDF transfer membrane (Millipore, IPVH00010) at $4^{\circ} \mathrm{C}$. Blots were blocked for $2 \mathrm{~h}$ with $5 \%$ $(\mathrm{w} / \mathrm{v})$ non-fat milk in TBST buffer at room temperature with shaking. Primary antibody mentioned above against the indicated protein was diluted in TBST buffer (B23, 1:4000; Fibrillarin, 1:4000; C23, 1:3500). Anti- $\beta$ actin monoclonal antibody (Abmart, P30002) was used for the internal control. The soaked PVDF membrane was subsequently incubated with primary antibody for $2.5 \mathrm{~h}$ at room temperature on the rocker platform and then washed with TBST buffer two times for $10 \mathrm{~min}$ each and TBS buffer one time for $10 \mathrm{~min}$. The HRPconjugated secondary antibody (Promega, W4021) diluted 1:7000 in TBST buffer was added for $2 \mathrm{~h}$. After another three washes, the blots were detected using the ECL technique (Millipore, WBKL S0100) and exposed to the X-ray film. The intensities of the bands in the film were measured by software "Quantity One" (Bio-Rad). During the experiment, care was taken to prevent membrane from drying.

\section{Statistical analysis}

Each treatment was replicated 3 times for statistical validity. SPSS computer software was used for statistical analyses (SPSS Japan Inc., Shibuya, Tokyo, Japan) and SigmaPlot 8.0 software was used for mapping. Any differences between treatments were determined using one-way analysis of variance (ANOVA), and scored as significant if $(P<0.05)$. The means and standard errors of the means mean $\pm \mathrm{SE}$ are reported. For Western blotting statistical analysis, independent-samples $t$-test was used to determine the significance at $P<0.05$ using SPSS 15.0 version for Windows software.

\section{Competing interests}

The authors declare that they have no competing interests.

\section{Authors' contributions}

$\mathrm{HHZ}$ carried out the entire experiments, participated in drafted the manuscript. $\mathrm{ZJ}$ and RQ participated in indirect immunofluorescent studies and Western blotting analysis. HNZ and JHZ participated in element determination and the data analysis. WSJ drafted and revised the manuscript with DHL. DHL conceived the study, and participated in its design and coordination. All authors read and approved the final manuscript.

\section{Acknowledgements}

This work was supported by the National Natural Science Foundation of China. The authors wish to express their appreciation to the reviewers for this paper.

\section{Author details}

${ }^{1}$ Tianjin Key Laboratory of Animal and Plant Resistance, College of Life Sciences, Tianjin Normal University, Tianjin 300387, PR China. ${ }^{2}$ School of Life Science, South China Normal University, Guangzhou, Guangzhou 510631, PR China.

Received: 14 May 2014 Accepted: 25 September 2014

Published online: 30 September 2014

\section{References}

1. Matsumoto $\mathrm{H}$, Motoda $\mathrm{H}$ : Aluminum toxicity recovery processes in root apices; possible association with oxidative stress. Plant Sci 2012, 186:1-8.

2. Silva S: Aluminium toxicity targets in plants. J Bot 2012, 219462:8. doi:10.1155/2012/219462.

3. Wang JW, Kao $\mathrm{CH}$ : Reduction of aluminum-inhibited root growth of rice seedlings with supplemental calcium, magnesium and organic acids. Crop Environ Bioinfor 2004, 1:191-198.

4. Lilienfein J, Qualls RG, Uselman SM, Bridgham SD: Soil formation and organic matter accretion in a young andesitic chronosequence at Mt. Shasta, California. Geoderma 2003, 116:249-264.

5. Tahara K, Yamanoshita T, Norisada M, Hasegawa I, Kashima H, Sasaki S, Kojima K: Aluminum distribution and reactive oxygen species accumulation in root tips of two Melaleuca trees differing in aluminum resistance. Plant Soil 2008, 307:167-178.

6. Kochian LV, Piñeros MA, Hoekenga OA: The physiology, genetics and molecular biology of plant aluminum resistance and toxicity. Plant Soil 2005, 274:175-195.

7. Poot-Poot W, Hernandez-Sotomayor SM: Aluminum stress and its role in the phospholipid signaling pathway in plants and possible biotechnological applications. IUBMB Life 2011, 63:864-872.

8. Matsumoto $H$, Senoo $Y$, Kasai M, Maeshima M: Response of the plant root to aluminum stress: analysis of the inhibition of the root elongation and changes in membrane function. J Plant Res 1996, 9:99-105.

9. Vitorello VA, Capaldi FR, Stefanuto VA: Recent advances in aluminum toxicity and resistance in higher plants. Braz J Plant Physiol 2005, 17:129-143.

10. Jansen S, Broadley MR, Robbrecht E: Aluminum hyperaccumulation in angiosperms: a review of its phylogenetic significance. Bot Rev 2002, 68:235-269.

11. Verstraeten SV, Aimo L, Oteiza PI: Aluminium and lead: molecular mechanisms of brain toxicity. Arch Toxicol 2008, 82:789-802.

12. Arunakumara KKIU, Walpola BC, Yoon MH: Aluminum toxicity and tolerance mechanism in cereals and legumes - a review. J Korean Soc Appl Biol Chem 2013, 56:1-9.

13. Huang CF, Yamaji N, Nishimura M, Tajima S, Ma JF: A rice mutant sensitive to Al toxicity is defective in the specification of root outer cell layers. Plant Cell Physiol 2009, 50:976-985.

14. Barceló J, Poschenrieder C: Fast root growth responses, root exudates, and internal detoxification as clues to the mechanisms of aluminium toxicity and resistance: a review. Environ Exp Bot 2002, 48:75-92.

15. Yang J, Wei HB, Li F, Yi SL: The effect of high-pressure and high-temperature drying treatments on the deresination ratio of Pinus massoniana. For Sci Pract 2013, 15:76-80.

16. Zhang $Y$, Zhou ZC, Ma XH: Foraging ability and growth performance of four subtropical tree species in response to heterogeneous nutrient environments. J For Resh 2010, 15:91-98.

17. Guo JH, Liu XJ, Zhang Y, Shen JL, Han WX, Zhang WF, Christie P, Goulding KWT, Vitousek PM, Zhang FS: Significant acidification in major Chinese croplands. Science 2010, 327:1008-1010.

18. Godbold DL, Fritz E, Huttermann A: Aluminum toxicity and forest decline. Proc Natl Acad Sci U S A 1988, 85:3888-3892.

19. Fiskesjö G: The Allium test as a standard in environmental monitoring. Hereditas 1985, 102:99-112. 
20. Osaki MT, Watanabe T, Tadano T: Beneficial effect of aluminum on growth of plants adapted to low pH soils. Soil Sci Plant Nutr 1997, 43:551-563.

21. Watanabe T, Jansen S, Osaki M: Al-Fe interactions and growth enhancement in Melastoma malabathricum and Miscanthus sinensis dominating acid sulphate soils. Plant Cell Environ 2006, 29:2124-2132.

22. Waraich E, Ahmad A, Ashraf R, Saifullah MY, Ahmad M: Improving agricultural water use efficiency by nutrient management in crop plants. Acta Agr Scand B-S P 2011, 61:291-304.

23. Pécsváradi A, Nagy Z, Varga A, Vashegyi Á, Labádi I, Galbács G, Zsoldos F: Chloroplastic glutamine synthetase is activated by direct binding of aluminium. Physiol Plant 2009, 135:43-50.

24. Bose J, Babourina O, Rengel Z: Role of magnesium in alleviation of aluminum toxicity in plants. J Exp Bot 2011, 62:2251-2264.

25. Marschner H: Mineral Nutrition of Higher Plants. London, San Diego: Academic Press; 1995.

26. Chen ZC, Ma JF: Magnesium transporters and their role in Al tolerance in plants. Plant Soil 2013, 368:51-56.

27. Alam SM: Influence of aluminum on plant growth and mineral nutrition of barley. Commun Soil Sci Plan 1981, 12:121-138.

28. Alam SM: Effect of aluminum on the dry matter and mineral content of rice. J Sci Technol 1983, 7:1-3.

29. Mariano ED, Keltjens WG: Long-Term Effects of aluminum exposure on nutrient uptake by maize genotypes differing in aluminum resistance. J Plant Nutr 2005, 28:323-333.

30. Guo TR, Zhang GP, Wu FB, Chen JX, Zhou MX: Genotypic difference in plant growth and mineral composition in Barley under aluminum stress. Agric Sci 2003, 2:494-501

31. Mohanty $S$, Das AB, Das P, Mohanty P: Effect of a low dose of aluminum on mitotic and meiotic activity, 4C DNA content, and pollen sterility in rice, Oryza sativa L. cv. Lalat. Ecotoxicol Environ Saf 2004, 59:70-75.

32. Clarkson DT: The effect of Al and some other trivalent metal cations on cell division in the root apices of Allium cepa. Ann Bot 1965, 29:309-315.

33. Doncheva S, Amenós M, Poschenrieder C, Barceló J: Root cell patterning: a primary target for aluminum toxicity in maize. J Exp Bot 2005, 56:1213-1220

34. Meda AR, Furlani PR: Tolerance to aluminum toxicity by tropical leguminous plants used as cover crops. Braz Arch Biol Technol 2005, 48:309-317.

35. Grant WF: Chromosome aberrations in plants as a monitoring system. Environ Health Perspect 1978, 27:37-43.

36. Liu DH, Jiang WS, Li DS: Effects of aluminium ion on root growth, cell division, and nucleoli of garlic (Allium sativum L.). Environ Pollut 1993, 82:295-299.

37. Zou JH, Yue JY, Jiang WS, Liu DH: Effects of cadmium stress on root tip cells and some physiological indexes in Allium cepa var. agrogarum $\mathrm{L}$. Acta Biologica Cracov Bot 2012, 54:129-141.

38. Zou JH, Wang M, Jiang WS, Liu DH: Effects of hexavalent chromium (VI) on root growth and cell division in root tip cells of Amaranthus viridis $\mathrm{L}$ Pak J Bot 2006, 38:673-681.

39. Ahmed M, Grant WF: Cytological effects of the mercurial fungicide, Panogen 15 on Tradescantia and Vicia faba root tips. Mutat Res 1972, 14:391-396

40. Darlington CD: Chromosome chemistry and gene action. Nature 1942, 149:66-69.

41. Kaufman BP: Cytochemical studies of changes induced in cellular materials by ionizing radiations. Ann N Y Acad Sci 1955, 59:553-566.

42. Levan A: The effect of colchicine on root mitoses in Allium. Hereditas 1938, 24:471-486.

43. Seth CS, Misra V, Chauhan LKS, Singh RR: Genotoxicity of cadmium on root meristem cells of Allium cepa: cytogenetic and Cometassay approach. Ecotoxicol Environsaf 2008, 71:711-716.

44. Morimura S, Matsumoto $\mathrm{H}$ : Effect of aluminium on some properties and template activity of purified pea DNA. Plant Cell Physiol 1978, 19:429-436.

45. Morimura S, Takahashi $\mathrm{E}$, Matsumoto $\mathrm{H}$ : Association of aluminium with nuclei and inhibition of cell division in onion (Allium cepa) roots. $Z$ Pflanzenphysiol 1978, 88:395-401.

46. Matsumoto $\mathrm{H}$ : Changes of the structure of pea chromatin by aluminum. Plant Cell Physiol 1988, 29:281-287.

47. Rigoulet $M$, Yoboue ED, Devin A: Mitochondrial ROS generation and its regulation: mechanisms involved in $\mathrm{H}_{2} \mathrm{O}_{2}$ signaling. Antioxid Redox Signal 2011, 14:459-468.
48. Xu FJ, Li G, Jin CW, Liu WJ, Zhang SS, Zhang YS, Lin XY: Aluminum-induced changes in reactive oxygen species accumulation, lipid peroxidation and antioxidant capacity in wheat root tips. Biol Plant 2012, 56:89-96.

49. Staiger CJ: Signaling to the actin cytoskeleton in plants. Annu Rev Plant Physiol Plant Mol Biol 2000, 51:257-288.

50. Wasteneys GO, Galway ME: Remodelling the cytoskeleton for growth and form: an overview with some new views. Annu Rev Plant Biol 2003, 54:691-722.

51. Gardiner J, Overall R, Marc J: Putative Arabidopsis homologues of metazoan coiledcoil cytoskeletal proteins. Cell Biol Int 2011, 35:767-774.

52. Gardiner J, Overall R, Marc J: Plant microtubule cytoskeleton complexity: microtubule arrays as fractals. J Exp Bot 2012, 63:635-642.

53. Frantzios G, Galatis B, Apostolakos P: Aluminium effects on microtubule organization in dividing root-tip cells of Triticum turgidum. I Mitotic cells. New Phytol 2000, 145:211-224.

54. Pribyl P, Cepák V, Zachleder V: Cytoskeletal alterations in interphase cells of the green alga Spirogyra decimina in response to heavy metals exposure: II. The effect of aluminium, nickel and copper. Toxicol Vitro 2008, 22:1160-1168.

55. Sivaguru M, Yamamoto $Y$, Matsumoto $H$ : Differential impacts of aluminium on microtubule organisation depends on growth phase in suspensioncultured tobacco cells. Physiol Plant 1999, 107:110-119.

56. MacDiarmid CW, Gardner RC: Al toxicity in yeast. A role for Mg? Plant Physiol 1996, 112:1101-1109.

57. Grabski S, Schindler M: Aluminum induces rigor within the actin network of soybean cells. Plant Physiol 1995, 108:897-901.

58. MacDonald TL, Humphreys WG, Martin RB: Promotion of tubulin assembly by aluminum ion in vitro. Science 1987, 236:183-186.

59. Xu Y: Structure and function of calmodulin (I). Biochem Biophys 1985, 1:22-27.

60. Trerè D: AgNOR staining and quantification. Micron 2000, 2:127-131.

61. Qin R, Jiao YQ, Zhang SS, Jiang WS, Liu DH: Effects of aluminum on nucleoli in root tip cells and selected physiological and biochemical characters in Allium cepa var agrogarum L. BMC Plant Biol 2010, 10:225.

62. Vostrikova TV, Butorina AK: Cytogenetic responses of birch to stress factors. Biol Bull 2006, 33:185-190.

63. Sheldon S, Speers WC, Lenhman JM: Nucleolar persistence in embryonal carcinoma cells. Exp Cell Res 1981, 132:185-192.

64. Zhang HM, Zhang SS, Meng QM, Zou J, Jiang WS, Liu DH: Effects of aluminum on nucleoli in root tip cells, root growth and the antioxidant defense system in Vicia faba L. Acta Biol Cracov Bot 2009, 51:99-106.

65. Fiskesjö G: Nucleolar dissolution induced by aluminium in root cells of Allium. Physiol Plant 1983, 59:508-511.

66. Fiskesjö G: Occurrence and degeneration of 'Al-structures' in root cap cells of Allium cepa L. after Al-treatment. Hereditas 1990, 112:193-202.

67. Liu DH, Jiang WS: Effects of $\mathrm{Al}^{3+}$ on the nucleolus in root tip cells of Allium cepa. Hereditas 1991, 115:213-219.

68. Qin R, Jiang WS, Liu DH: Aluminum can induce alterations in the cellular localization and expression of three major nucleolar proteins in root tip cells of Allium cepa var agrogarum L. Chemosphere 2013, 90:827-834.

69. Andersen JS, Lam YW, Leung AK, Ong SE, Lyon CE, Lamond Al, Mann M: Nucleolar proteome dynamics. Nature 2005, 433:77-83.

70. Olson MOJ, Dundr M: The moving parts of the nucleolus. Histochem Cell Biol 2005, 123:203-216

71. Boisvert FM, van Koningsbruggen S, Navascués J, Lamond Al: The multifunctional nucleolus. Nat Rev Mol Cell Biol 2007, 8:574-585.

72. Lischwe MA, Smetana K, Olson MOJ, Busch H: Proteins C23 and B23 are the major nucleolar silver staining proteins. Life Sci 1979, 25:701-708.

73. Ginisty $H$, Sicard $H$, Roger B, Bouvet $P$ : Structure and functions of nucleolin. J Cell Sci 1999, 112:761-772.

74. Strauss PR, Wilson SH: The Eukaryotic Nucleus: Molecular Biochemistry and Macromolecular Assemblies. Caldwell: The Telford Press; 1990.

75. Chen D, Huang S: Nucleolar components involved in ribosome biogenesis cycle between the nucleolus and nucleoplasm in interphase cells. J Cell Biol 2001, 153:169-176.

doi:10.1186/s12870-014-0264-9

Cite this article as: Zhang et al:: Accumulation and cellular toxicity of aluminum in seedling of Pinus massoniana. BMC Plant Biology 2014 14:264 